\title{
Kelayakan Standar Sarana dan Prasarana SMK Kompetensi Keahlian DPIB di Kota dan Kabupaten Bekasi (Studi Kasus di SMKN 6 Kota Bekasi dan SMKN 1 Cikarang Barat)
}

M. Agphin Ramadhan ${ }^{1 *}$, R. Eka Murtinugraha², Muhamad Subarkah ${ }^{3}$, 1,2,3 Universitas Negeri Jakarta

\begin{abstract}
This study aims to determine the feasibility of facilities and infrastructure of the Building Information Modeling (DPIB) Skills Competency Vocational School in Bekasi City and Regency in terms of Permendikbud No. 34 of 2018 and the Vocational Practice Exam Vocational School Verification Instrument issued by the National Education Standards Agency (BSNP). This research is a descriptive research method with a quantitative approach. Research data collection through observation, documentation and interviews. The data analysis used was descriptive statistics. The results of this study indicate that the feasibility level of the facilities and infrastructure of the DPIB Skills Competency Vocational School in Bekasi City in this case is SMK Negeri 6 Bekasi City, namely for the feasibility of class room facilities and the feasibility of practical room facilities with very feasible categories, for the availability of classroom facilities, feasibility of infrastructure. Classrooms and the availability of practical room facilities are categorized as feasible, while the feasibility of practice room infrastructure is categorized as less feasible. The feasibility level of the DPIB Skills Competency Vocational School in Bekasi Regency, in this case SMK Negeri 1 Cikarang Barat, is the feasibility of class room facilities and the feasibility of practice room facilities is categorized as very feasible, for the availability of classroom facilities, the availability of practice room facilities and the feasibility of practice room infrastructure are categorized as feasible., while the feasibility of practice room infrastructure is categorized as less feasible.
\end{abstract}

\begin{abstract}
ABSTRAK
Penelitian ini bertujuan untuk mengetahui kelayakan sarana dan prasarana SMK Kompetensi Keahlian Desain Pemodelan dan Informasi Bangunan (DPIB) di Kota dan Kabupaten Bekasi ditinjau dari Permendikbud No. 34 Tahun 2018 dan Instrumen Verifikasi SMK Penyelenggara Ujian Praktik Kejuruan yang dikeluarkan oleh Badan Standar Nasional Pendidikan (BSNP). Penelitian ini merupakan metode penelitian deskriptif dengan pendekatan kuantitatif. Pengumpulan data penelitian melalui observasi, dokumentasi dan wawancara. Analisis data yang digunakan adalah statistik deskriptif. Hasil penelitian ini menununjukkan bahwa tingkat kelayakan sarana dan prasarana SMK Kompetensi Keahlian DPIB di Kota Bekasi dalam hal ini adalah SMK Negeri 6 Kota Bekasi yaitu untuk kelayakan sarana ruang kelas dan kelayakan sarana ruang praktik dengan kategori sangat layak, untuk ketersediaan sarana ruang kelas, kelayakan prasarana ruang kelas dan ketersediaan sarana ruang praktik termasuk kategori layak, sedangkan kelayakan prasarana ruang praktik dikategorikan kurang layak. Tingkat kelayakan SMK Kompetensi Keahlian DPIB di Kabupaten Bekasi dalam hal ini SMK Negeri 1 Cikarang Barat yaitu untuk kelayakan sarana ruang kelas dan kelayakan sarana ruang praktik dikategorikan sangat layak, untuk ketersediaan sarana ruang kelas, ketersediaan sarana ruang praktik dan kelayakan prasarana ruang praktik termasuk kategori layak, sedangkan kelayakan prasarana ruang praktik dikategorikan kurang layak.
\end{abstract}

CONTACT

agphin@unj.ac.id

KEYWORDS

Kelayakan, Sarana dan

Prasarana, Desain Pemodelan dan Informasi Bangunan

Received: 28/02/2021

Revised: $25 / 03 / 2021$

Accepted: 30/03/2021

Online: $25 / 04 / 2021$

Published: 30/04/2021

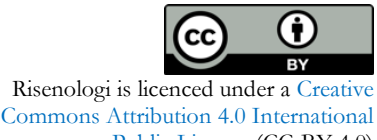

Public Licence (CC-BY 4.0)

\section{PENDAHULUAN}

Pendidikan merupakan salah satu kebutuhan manusia yang dalam pelaksanaannya disebut dengan belajar. Dalam belajar itulah terjadi perubahan mendasar yang terdri dari kebiasaan, pengetahuan dan sikap (Khairat, dkk, 2018), sehingga dengan adanya hal tersebut sudah seharusnya pihak sekolah dan pemerintah khususnya dinas pendidikan bekerjasama dengan baik guna meningkatkan mutu pendidikan, karena sekolah merupakan salah tempat siswa dapat belajar dengan baik. Meningkatkan mutu pembelajaran dipengaruhi oleh banyak faktor yang salah satunya adalah sarana dan prasarana pendidikan (Siswanto dan Hidayati, 2020).

Menurut Suliyarti (2019) bahwa sarana dan prasarana pendidikan di Kabupaten Bekasi masih buruk, hal tersebut dibuktikan dengan hingga akhir tahun 2018 jumlah ruang kelas yang tidak layak mencapai 9.686 unit, sedangkan 
ruang kelas yang layak hanya 3.198 unit. Data tersebut berdasarkan data yang diberikan oleh kepala dinas pendidikan (Dindik) Kabupaten Bekasi Maman Agus Supratman. Selain di Kabupaten Bekasi, fasilitas sarana prasarana seperti meja dan kursi di beberapa sekolah negeri di Kota Bekasi kondisinya sudah mulai sangat memprihatinkan, hal tersebut dibenarkan oleh Inayatulah selaku Kepala Dinas Pendidikan Kota Bekasi pada tahun 2020. Data tersebut pada sekolah tingkat dasar dan menengah dan tidak termasuk untuk Sekolah Menengah Kejuruan (SMK). Buruknya sarana dan prasarana pendidikan merupakan masalah nyata yang ada di Kabupaten Bekasi dan kondisi sarana prasarana pendidikan di Kota Bekasi yang sudah mulai memprihatinkan yang akan mengakibatkan menurunnya mutu pendidikan, karena salah satu standar nasional pendidikan dibidang sarana dan prasarana tidak terpenuhi.

Meningkatkan mutu pendidikan dapat dilakukan dengan ketersediaan sarana dan prasarana pendidikan, yang merupakan sebuah alat penunjang keberhasilan suatu proses pendidikan, karena apabila kedua hal tersebut tidak tersedia maka semua kegiatan yang dilakukan tidak akan mencapai hasil yang diharapkan sesuai dengan rencana (Agusti, dkk, 2014). Menurut Atmaja dan Maulana (2020) pendidikan yang baik diharapkan dapat memfasilitasi peserta didik secara maksimal sehingga berkontribusi positif untuk perkembangan dan pembangunan nasional, yang salah satu komponen pendidikan yang semestinya ada dalam pendidikan yaitu sarana dan prasarana. Sarana dan prasarana inilah merupakan komponen penting serta menjadi salah satu dari delapan Standar Nasional Pendidikan (SNP). Menurut Ilomo dan Mlavi (2016) mengemukakan bahwa kurangnya sarana dan prasarana atau infrastruktur sekolah seperti laboratorium, perpustakaan dan ruang kelas menyebabkan siswa memiliki prestasi akademik yang buruk. Pemahaman tentang manajemen kelayakan Sarana prasarana penting secara langsung dan tidak langsung kepada siswa (Sabella, 2020).

Pada tahun 2018 spektrum pendidikan di SMK mengalami perubahan. Menurut Peraturan Dirjen Pendidikan Dasar dan Menengah No. 06/D.D5/KK/2018, perubahan spektrum keahlian SMK/MAK yang saat ini berlaku perlu disesuaikan dan sejalan dengan tuntutan perkembangan teknologi, kurikulum, ilmu pengetahuan, seni, dinamika perkembangan global dan kebutuhan dunia kerja. Salah satu spektrum pendidikan SMK yang berubah terdapat pada Program Keahlian Teknologi Konstruksi dan Properti yang memiliki empat kompetensi keahlian yaitu : (1) Konstruksi Gedung, Sanitasi dan Perawatan (KGSP), (2) Konstruksi Jalan, Irigasi dan Jembatan (KJIJ), (3) Bisnis Konstruksi dan Properti (BKP), dan (4) Desain Pemodelan dan Informasi Bangunan (DPIB). Hal itulah yang mengakibatkan pihak sekolah harus cepat menyesuaikan sarana dan prasarana sekolah terhadap spektrum pendidikan yang baru.

Salah satu dari empat SMK dengan program keahlian Teknologi Konstruksi dan Properti yang menarik untuk dibahas adalah kompetensi keahlian DPIB yang berada di Kota dan Kabupaten Bekasi. Dapat dikatakan menarik karena SMK yang menyelenggarakan pendidikan kompetensi keahlian DPIB di Bekasi yang masih sedikit, hal ini akan berpengaruh terhadap pemenuhan tenaga kerja menengah bidang konstruksi. Menurut Dirjen Bina Konstruksi (2019) kebutuhan pembangunan infrastruktur membutuhkan sumber daya manusia yang tidak sedikit, salah satu cara untuk dapat menyiapkan tenaga kerja siap pakai adalah dengan pendidikan vokasi. Salah satu pendidikan vokasi yang terkait dengan konstruksi salah satunya yaitu SMK dengan Kompetensi Keahlian DPIB. Sudiyono dan Alip (2016) mengemukakan bahwa lulusan dari SMK diharapkan sudah mampu untuk memasuki dunia kerja dan mampu menjadi tenaga kerja tingkat menengah untuk memenuhi kebutuhan dunia usaha dan industri pada saat ini dan di masa yang akan datang.

Berdasarkan Rencana Strategis Dinas Pendidikan Kota Bekasi Tahun 2018 - 2023 menyatakan bahwa sarana prasarana menjadi faktor penting yang berpengaruh secara langsung terhadap keberhasilan penyelenggaraan pendidikan di sekolah. Menurut Laporan Kinerja Instansi Pemerintah (LKIP) Jawa Barat Tahun 2018, Bekasi merupakan salah satu kota dan kabupaten yang berada di Jawa Barat memiliki posisi penting yang sangat strategis, antara lain: kondisi demografis, sebagai lumbung pangan nasional, pusat industri manufaktur, pusat pendidikan dan penelitian nasional. Hal inilah yang membuat lulusan SMK yang berada di wilayah Bekasi untuk siap terjun ke dunia industri dan dunia usaha. Namun hal tersebut belum ditopang dengan ketersediaan SMK Kompetensi Keahlian Desain Pemodelan dan Informasi Bangunan (DPIB) di wilayah Bekasi yang belum memadai, karena hanya masing-masing wilayah terdapat satu sekolah. Di Kota Bekasi terdapat 15 SMK Negeri dan 132 SMK Swasta (Data Pokok SMK Kemdikbud tahun 2020), dan hanya terdapat satu sekolah dengan program keahlian DPIB yaitu SMK Negeri 6 Kota Bekasi. Di Kabupaten Bekasi terdapat 15 SMK Negeri dan 173 SMK Swasta, serta hanya di SMK Negeri 1 Cikarang Barat yang menyediakan program keahlian Desain Pemodelan dan Informasi Bangunan (Data Pokok SMK Kemdikbud tahun 2020).

SMK Negeri 6 Kota Bekasi merupakan satu-satunya sekolah yang membuka kompetensi keahlian Desain Pemodelan dan Informasi Bangunan di Kota Bekasi. Berdasarkan observasi dan pengamatan langsung di lapangan, terdapat kendala dan permasalahan terkait pemanfaatan sarana dan prasarana. Contohnya adalah dari segi pemenuhan kebutuhan sarana dan prasarana yang ada, SMK Negeri 6 Kota Bekasi masih memiliki kekurangan 
ruangan, seperti tidak tersedianya ruang laboratorium gambar manual, laboratorium fisika, dan laboratorium lainnya, bahkan ruang laboratorium pun diubah menjadi ruang guru. Kendala yang lain adalah tidak terdapatnya meja gambar siswa. Alhasil siswa menggambar menggunakan meja belajar biasa di kelas yang kualitasnya pun sudah mulai rusak yaitu meja yang tidak rata. Kondisi ruang kelas umum di program keahlian DPIB ketika siang hari juga membuat siswa merasa tidak nyaman karena ruang kelas terasa panas. Ruang kelas di SMK Negeri 6 Kota Bekasi hanya mengandalkan sirkulasi udara dari jendela dan kipas angin dengan beberapa kondisi tidak menyala atau rusak. Menurut Tambunan, dkk (2020) mengemukakan bahwa ruang kelas di SMK Negeri 6 Kota Bekasi cukup panas atau gerah. Hal inilah yang bisa menjadi penghambat pemenuhan Standar Nasional Pendidikan (SNP) di bidang sarana dan prasarana.

Serupa dengan dengan di SMK Negeri 6 Kota Bekasi, di SMK Negeri 1 Cikarang Barat juga merupakan satusatunya SMK yang memiliki Kompetensi Keahlian Desain Pemodelan dan Informasi Bangunan yang ada di Kabupaten Bekasi. Dilihat dari segi pemenuhan sarana dan prasarana sekolah, SMK Negeri 1 Cikarang Barat lebih lengkap daripada SMK Negeri 6 Kota Bekasi, akan tetapi pemenuhan kebutuhan dari segi kualitas dan kuantitas masih kurang memadai. Berdasarkan hasil wawancara kepada mahasiswa yang sedang melaksanakan Praktek Keterampilan Mengajar (PKM) di SMK Negeri 1 Cikarang Barat pada bulan April 2020, misalnya saja terdapat alat waterpas dan meteran yang digunakan siswa pada saat praktek ilmu ukur tanah sudah banyak yang rusak. Selain hal tersebut, masih terdapat kendala yaitu tidak tersedianya fasilitas laboratorium gambar manual, laboratorium fisika dan laboratorium kimia. Tidak terdapatnya fasilitas mesin penyejuk udara juga mengakibatkan kondisi ruang kelas menjadi panas. Suasana ruang kelas yang panas atau gerah dapat mengganggu konsentrasi siswa, sehingga tak kondusif (Tambunan, dkk, 2020). Pada saat pelajaran menggambar teknik tidak terdapat fasilitas meja gambar sehingga siswa menggambar di meja belajar yang ada di ruang kelas dan kondisinya sudah mulai rusak atau tidak rata. Walaupun letak sekolah berada di wilayah strategis yang berdekatan dengan kawasan industri, tidak luput dari beberapa kekurangan.

Berdasarkan dari penjabaran di atas terdapat beberapa sarana dan prasarana yang kurang memadai, atau menggunakan ruangan yang tidak semestinya. Tidak lengkapnya atau tidak terpenuhinya fungsi sarana dan prasarana sekolah akan menimbulkan kendala dalam proses belajar mengajar (Havidotinnisa, 2016). Ketersediaan sarana dan prasarana pendidikan di sekolah yang kurang lengkap akan berdampak memperlambat proses pembelajaran (Syafiq dan Sofyan, 2018). Serupa dengan yang dikemukakan oleh Siswanto dan Hidayati (2020) bahwa fasilitas pendidikan yang terpenuhi dan memadai akan mendukung sistem belajar mengajar. Sarana dan prasarana sekolah inilah yang seharusnya layak dan memadai sehingga membuat siswa nyaman dan dapat belajar dengan baik. Jannah dan Sontani (2018) mengemukakan bahwa sarana dan prasarana pembelajaran sangatlah penting terutama akan menumbuhkan motivasi belajar para siswa dan nantinya akan berpengaruh terhadap motivasi belajar siswa. Akhirnya, hal tersebut berpengaruh terhadap pemenuhan dari minimal standar sarana dan prasarana serta berpengaruh terhadap kinerja Kompetensi Keahlian Desain Pemodelan dan Informasi Bangunan.

Sarana pendidikan mencangkup semua peralatan serta perlengkapan yang secara langsung digunakan sebagai penunjang proses pendidikan, sedangkan prasarana pendidikan mencangkup semua peralatan dan perlengkapan yang digunakan secara tidak langsung untuk menunjang proses pembelajaran (Atmaja dan Maulana, 2020).

Kelayakan sarana adalah semua peralatan dan perabot yang digunakan secara langsung pada proses pembelajaran yang jumlahnya mencukupi dengan siswa yang menggunakan dan berfungsi sebagaimana mestinya, sedangkan kelayakan prasarana merupakan kelengkapan dasar yang digunakan secara tidak langsung dalam proses pembelajaran yang jumlahnya mencukupi dengan siswa yang menggunakan serta berfungsi sebagaimana mestinya (Syafiq dan Sofyan, 2018), untuk mengukur atau menilai sebuah tingkat kelayakan diperlukan sebuah acuan sebagai standarisasi, standar yang digunakan saat ini adalah Permendikbud No. 34 Tahun 2018 tentang Standar Nasional Pendidikan Sekolah Menengah Kejuruan/Madrasah Aliyah Kejuruan. Selain Permendikbud No. 34 Tahun 2018, acuan yang digunakan untuk standar sarana dan prasarana pendidikan adalah instrumen verifikasi yang digunakan untuk penyelenggaraan ujian praktik kejuruan di SMK/MAK Tahun Ajaran 2019/2020 yang dikeluarkan oleh Badan Standar Nasional Pendidikan (BSNP).

Belum diketahuinya seberapa besar tingkat kelayakan sarana dan prasarana sekolah pada kompetensi keahlian Desain Pemodelan dan Informasi Bangunan (DPIB) di Kota dan Kabupaten Bekasi juga merupakan salah satu hal yang melatarbelakangi peneliti untuk menjadikan sekolah dengan Kompetensi Keahlian DPIB di Kota dan Kabupaten Bekasi supaya menjadi optimal sebagai langkah membantu dalam meningkatkan kualitas pendidikan nasional, maka dari itu peneliti menyusun sebuah penelitian pendidikan dengan judul "Kelayakan Standar Sarana dan Prasarana SMK Kompetensi Keahlian DPIB di Kota dan Kabupaten Bekasi”. 


\section{METODE PENELITIAN}

Metode penelitian yang digunakan pada penelitian ini adalah metode penelitian deskriptif dengan menggunakan pendekatan kuantitatif. Metode deskriptif dalam penelitian ini yaitu digunakan untuk mengukur tingkat kelayakan sarana dan prasarana pendidikan yang berada pada SMK Kompetensi Keahlian DPIB di Kota dan Kabupaten Bekasi. Sampel dalam penelitian ini yaitu sarana dan prasarana ruang kelas dan ruang praktik. Teknik pengumpulan data menggunakan dokumentasi, observasi dan wawancara. Penelitian ini menggunakan teknik analisis data statistik deskriptif, sehingga tidak ada uji signifikansi dan taraf kesalahan, karena penelitian ini tidak bermaksud membuat kesimpulan untuk umum atau generalisasi.

Instrumen yang digunakan pada penelitian ini disesuaikan dengan metode pengumpulan datanya. Metode pengumpulan data melalui dokumentasi, observasi dan wawancara dengan menggunakan daftar isian yang di dalamnya termuat standar sarana dan prasarana yang berpedoman pada Permendikbud No. 34 Tahun 2018 tentang Standar Nasional Pendidikan Sekolah Menengah Kejuruan/Madrasah Aliyah Kejuruan pada salinan Lampiran VI yang membahasa tentang Standar Sarana dan Prasarana dan Instrumen Verifikasi Ujian Praktik Kejuruan yang diterbitkan oleh Badan Standar Nasional Pendidikan (BSNP).

Tabel 1. Instrumen Standar Sarana Ruang Kelas

\begin{tabular}{lll}
\hline No. & \multicolumn{1}{c}{ Indikator } & \multicolumn{1}{c}{ Sub Indikator } \\
\hline 1. & Perabot & Kursi peserta didik \\
& & Meja peserta didik \\
& & Kursi guru \\
& & Meja guru \\
& & Lemari \\
& & Papan tulis
\end{tabular}

3. Perlengkapan lain Stop kontak

Sumber: Permendikbud No. 34 Tahun 2018 tentang Standar Nasional Pendidikan Sekolah Menengah Kejuruan/Madrasah Aliyah Kejuruan

Tabel 2. Instrumen Standar Prasarana Ruang Praktik

\begin{tabular}{lll}
\hline No. & \multicolumn{1}{c}{ Indikator } & \multicolumn{1}{c}{ Sub Indikator } \\
\hline 1 & Ruang praktik desain masinal dan komputer & Ruang praktik komputer \\
2 & Ruang praktik perencanaan dan pembuatan & Ruang pembuatan maket \\
& model/maket bangunan & bangunan \\
3 & Sub ruang instruktur dan ruang simpan & Ruang instruktur \\
\hline
\end{tabular}

Sumber: Permendikbud No. 34 Tahun 2018 tentang Standar Nasional Pendidikan Sekolah Menengah Kejuruan/Madrasah Aliyah Kejuruan

Tabel 3. Instrumen Standar Sarana Ruang Praktik

\begin{tabular}{lll}
\hline No. & \multicolumn{1}{c}{ Indikator } & \multicolumn{1}{c}{ Sub Indikator } \\
\hline 1. & Perabot & Kursi kerja \\
& & Meja kerja \\
& Meja alat \\
& Meja persiapan \\
& Lemari alat (tools cabinet) \\
& & Lemari \\
& & Komputer \\
2. $\quad$ Peralatan & Program/software \\
& & Printer A3/A4 \\
& & Stavolt/UPS \\
& & Papan tulis \\
3. & Media pendidikan & Papan tugas/kemajuan siswa \\
& & Stop kontak \\
4. & Perlengkapan lain & Alat-alat K3 \\
& &
\end{tabular}


Sumber: Permendikbud No. 34 Tahun 2018 tentang Standar Nasional Pendidikan Sekolah Menengah Kejuruan/Madrasah Aliyah Kejuruan

Analisis data dalam penelitian ini menggunakan skala persentase yaitu perhitungan dalam analisis data yang akan menghasilkan persentase yang selanjutnya dilakukan interpretasi pada nilai yang telah diperoleh, sehingga proses perhitungan persentase dilakukan dengan cara mengalikan skor yang diperoleh dengan skor ideal dengan seratus persen. Sebelum memperoleh hasil akhir persentase kelayakan, maka hal pertama adalah mencari ketersediaan dengan rumus :

$$
\text { Ketersediaan }(\%)=\frac{\text { jumlah tersedia }}{j \text { umlah minimal }} \times 100 \%
$$

Gambar 1. Rumus Ketersediaan

Setelah mendapatkan persentase ketersediaan, berikutnya yaitu menentukan skor penilaian ketersediaan dengan ketentuan menggunakan skala likert yang dijabarkan pada pada tabel berikut :

Tabel 4. Kriteria Skor Penilaian Ketersediaan

\begin{tabular}{cl}
\hline Skor & \multicolumn{1}{c}{ Keterangan } \\
\hline 1 & $\begin{array}{l}\text { Apabila sarana dan prasarana tidak ada atau persentase ketersediaan } \\
=0 \%-49 \% .\end{array}$ \\
2 & $\begin{array}{l}\text { Apabila sarana dan prasarana tetapi belum mencukupi dan tidak } \\
\text { sesuai dengan standar atau persentase ketersediaan } 50 \%-99 \% .\end{array}$ \\
3 & $\begin{array}{l}\text { Apabila sarana dan prasarana ada dan sesuai dengan standar yang } \\
\text { berlaku atau persentase ketersediaan }=100 \% .\end{array}$ \\
4 & $\begin{array}{l}\text { Apabila sarana dan prasarana jumlahnya telah melibihi dari standar } \\
\text { yang berlaku atau persentase ketersediaan }>100 \% .\end{array}$ \\
\hline
\end{tabular}

Terakhir, setelah mendapatkan jumlah skor kemudian mencari persentase kelayakan akhir. Proses perhitungan persentase dilakukan dengan cara membagi jumlah yang tersedia dengan jumlah kebutuhan, kemudian dikalikan seratus persen.

$$
\text { Kelayakan }(\%)=\frac{\text { skor yang diperoleh }}{\text { skor } \text { ideal }} \times 100 \%
$$

Gambar 2. Rumus Kelayakan

Skala yang digunakan pada penelitian ini menggunakan rating scale (skala bertingkat), langkah berikutnya adalah mendeskripsikan dan mengambil kesimpulan tentang masing-masing indikator menggunakan kriteria yang telah ditentukan oleh peneliti yakni menggunakan sebagai berikut :

Tabel 5. Kriteria Penilaian Kelayakan Akhir

\begin{tabular}{ccc}
\hline No. & Definisi & Kriteria Pencapaian \\
\hline 1 & Sangat Layak & $76 \%-100 \%$ \\
2 & Layak & $51 \%-75 \%$ \\
3 & Kurang Layak & $26 \%-50 \%$ \\
4 & Tidak Layak & $0 \%-25 \%$ \\
\hline \multicolumn{3}{c}{ (Sumber : Sugiyono, 2018) }
\end{tabular}

\section{HASIL PENELITIAN DAN PEMBAHASAN}

Kelayakan sarana dan prasarana kompetensi keahlian DPIB yang ditinjau dari aspek ketersediaan dan kelayakan fasilitas yang digunakan siswa pada ruang kelas dan ruang praktik dapat diketahui dengan cara membandingkan data hasil observasi yang diperoleh dengan data standarisasi yang digunakan sebagai acuan dalam penelitian ini.

\section{Kelayakan Sarana Ruang Kelas}

Sarana ruang kelas yang diamati pada Kompetensi keahlian DPIB terdapat 3 komponen yaitu perabot, media pendidikan, dan perlengkapan lain. Berdasarkan hasil dari observasi dan analisis data bahwa rata-rata ketersediaan sarana ruang kelas SMK Kompetensi Keahlian DPIB di Kota Bekasi sebesar 75,89\% dengan kategori layak dan 
lebih tinggi dibandingkan SMK Kompetensi Keahlian DPIB di Kabupaten Bekasi sebesar 57,65\% dengan kategori layak. Berikut ini adalah diagram rekapitulasi rata-rata ketersediaan sarana ruang kelas Kompetensi keahlian DPIB yang ditunjukkan pada gambar 3 .

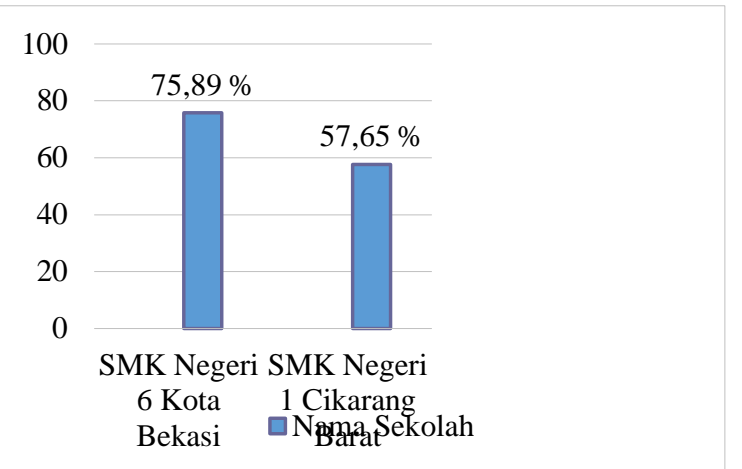

Gambar 3. Rekapitulasi Ketersediaan Sarana Ruang Kelas

Untuk kelayakan sarana ruang kelas yang ada, dapat disimpulkan bahwa rata-rata kelayakan sarana ruang kelas SMK Kompetensi Keahlian DPIB di Kota Bekasi sebesar 97,80\% dengan kategori sangat layak dan lebih tinggi dibandingkan SMK Kompetensi Keahlian DPIB di Kabupaten Bekasi sebesar 96,30\% dengan kategori sangat layak. Berikut ini adalah diagram rekapitulasi rata-rata kelayakan sarana ruang kelas Kompetensi Keahlian DPIB yang ditunjukkan pada gambar 4.

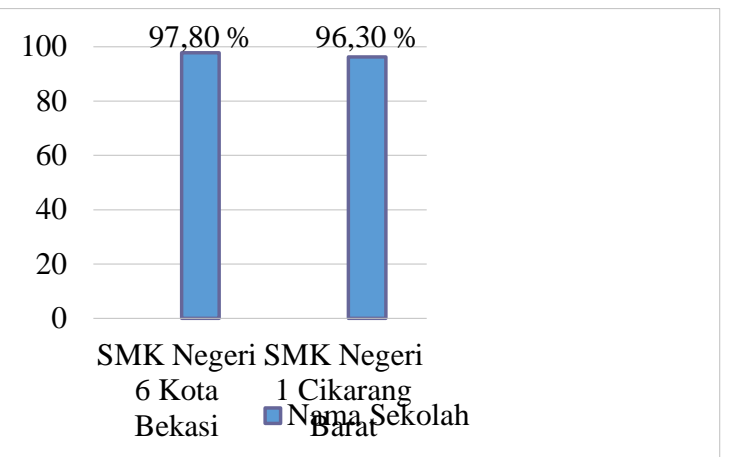

Gambar 4. Rekapitulasi Kelayakan Sarana Ruang Kelas

Berkaitan dengan ketersediaan dan kelayakan sarana ruang kelas membuktikan bahwa masih tingginya tingkat kesadaran pengguna sarana ruang kelas untuk merawat sarana ruang kelas yang digunakan untuk kegiatan belajar mengajar di dalam kelas, namun masih terdapat beberapa sarana ruang kelas dengan kondisi rusak yang rata-rata kerusakannya paling banyak di bagian terkelupasnya lapisan kursi, walaupun masih bisa dipakai akan tetapi akan mempengaruhi kenyamanan siswa yang menggunakannya. Oleh karena itu, pihak sekolah dapat memperbaikinya dan dapat menambah semua sarana dan prasarana ruang kelas yang belum tersedia, serta semua pihak dapat merawat sarana ruang kelas dengan baik, supaya tidak ada lagi sarana ruang kelas dengan kondisi tidak baik atau rusak. Semakin baik dan semakin ditingkatkannya sarana sekolah, maka hasil belajar siswa juga akan meningkat (Miski, 2015).

\section{Kelayakan Prasarana Ruang Kelas}

Berdasarkan Permendikbud Nomor 34 Tahun 2018 jumlah ruang kelas adalah setengah dari jumlah rombongan belajar (rombel) dan rasio luas ruangan yaitu $2 \mathrm{~m}^{2}$. Ruang kelas DPIB di SMK Negeri 6 Kota Bekasi memiliki 6 rombongan belajar dengan 4 ruang kelas dan rata-rata sudah memenuhi standar rasio ruangan yaitu $2 \mathrm{~m}^{2}$ untuk ruang kelas X DPIB 1, X DPIB 2, XI DPIB 1, serta untuk ruang kelas XII DPIB 1 dengan rasio ruang sebesar 2,18 $\mathrm{m}^{2}$ dan sudah melebihi dari ketentuan, sehingga kelayakan prasarana ruang kelas Kompetensi Keahlian DPIB di SMK Negeri 6 Kota Bekasi adalah 81,25\% dengan kategori sangat layak.

Ruang kelas DPIB di SMK Negeri 1 Cikarang Barat memiliki 11 rombongan belajar dengan 7 ruang kelas dan semua rasio ruang kelas sebesar $1,55 \mathrm{~m}^{2}$. Kelayakan prasarana ruang kelas kompetensi keahlian DPIB di SMK Negeri 1 Cikarang Barat adalah sebesar 50\% dengan ketegori kurang layak. Berdasarkan data tersebut dapat disimpulkan bahwa prasarana ruang kelas DPIB di Kota Bekasi lebih tinggi dibandingkan di Kabupaten Bekasi. 
Berikut ini adalah diagram rekapitulasi rata-rata kelayakan prasarana ruang kelas Kompetensi Keahlian DPIB yang ditunjukkan pada gambar 5 .

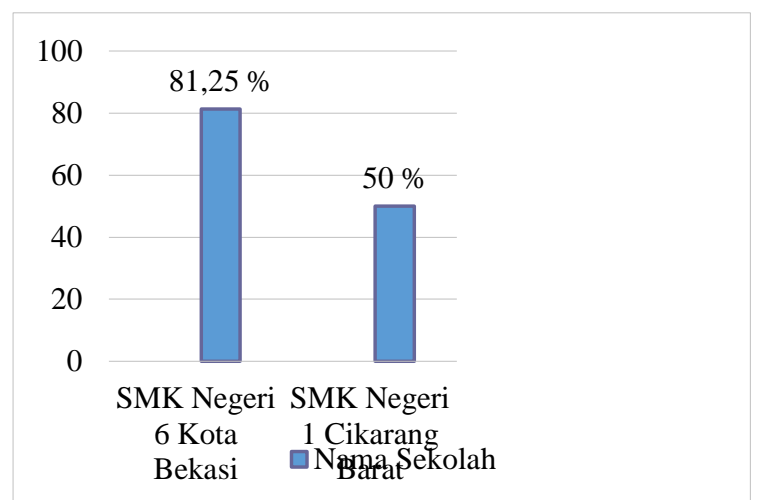

Gambar 5. Rekapitulasi kelayakan Prasarana Ruang Kelas

Dengan adanya data kelayakan prasarana ruang kelas tersebut diharapkan pihak sekolah dapat mempergunakan ruang kelas dengan baik sesuai jumlah rombel yang ada dan semua pihak dapat merawat prasarana ruang kelas dengan baik dan membersihkan ruang kelas dengan bersih supaya siswa dan guru merasa nyaman menggunakan ruang kelas. Suasana dan kenyamanan ruang belajar atau ruang kelas dapat berpengaruh terhadap konsentrasi belajar, hal tersebut sesuai dengan penelitian Andrianto,dkk (2020) yang mengemukakan bahwa kondisi ruang kelas akan mempengaruhi konsentrasi belajar siswa.

\section{Kelayakan Sarana Ruang Praktik}

Sarana ruang praktik DPIB SMK Negeri 6 Kota Bekasi sebagian besar sudah tersedia, namun terdapat sarana yang belum tersedia seperti papan tugas/kemajuan siswa dan sudah tersedia tetapi jumlahnya tidak memadai dengan jumlah standar yang ada seperti lemari alat dan meja persiapan untuk siswa. Berdasarkan hasil observasi didaptkan bahwa segi kebersihan sarana ruang praktik dikatakan bersih karena tidak ada sampah yang berserakan dan tidak ada coret noda pulpen naik di kursi maupun meja peserta didik. Ruang praktik DPIB terasa sejuk dan nyaman karena dibantu oleh alat Air Conditioner (AC) yang berfungsi dengan baik. Persentase ketersediaan sarana ruang praktik sebesar $67,86 \%$ dengan kategori layak.

Untuk sarana ruang praktik DPIB SMK Negeri 1 Cikarang Barat sebagian besar sudah tersedia, namun terdapat sarana yang belum tersedia seperti papan tugas/kemajuan siswa, stavolt/UPS dan alat-alat K3, serta sudah tersedia sarana tetapi jumlahnya tidak memadai dengan jumlah standar yang ada seperti lemari alat dan printer. Berdasarkan hasil observasi yang dilakukan didapatkan bahwa segi kebersihan sarana ruang praktik dikatakan bersih karena tidak ada sampah yang berserakan dan tidak ada coret noda pulpen baik di kursi maupun meja peserta didik. Ruang praktik DPIB terasa sejuk dan nyaman karena dibantu oleh alat Air Conditioner (AC) yang berfungsi dengan baik. Persentase ketersediaan sarana untuk ruang lab.komputer 1 dan 55,36\% dengan kategori layak, untuk ruang lab.komputer 2 persentase kelayakan 50\% dengan kategori layak dan rata-rata persentase kelayakan 52,68\% dengan kategori layak.

Berdasarkan data tersebut dapat disimpulkan bahwa ketersediaan sarana ruang praktik DPIB di Kota Bekasi lebih tinggi dibandingkan di Kabupaten Bekasi. Berikut ini adalah diagram rekapitulasi rata-rata ketersediaan sarana ruang praktik Kompetensi Keahlian DPIB yang ditunjukkan pada gambar 6.

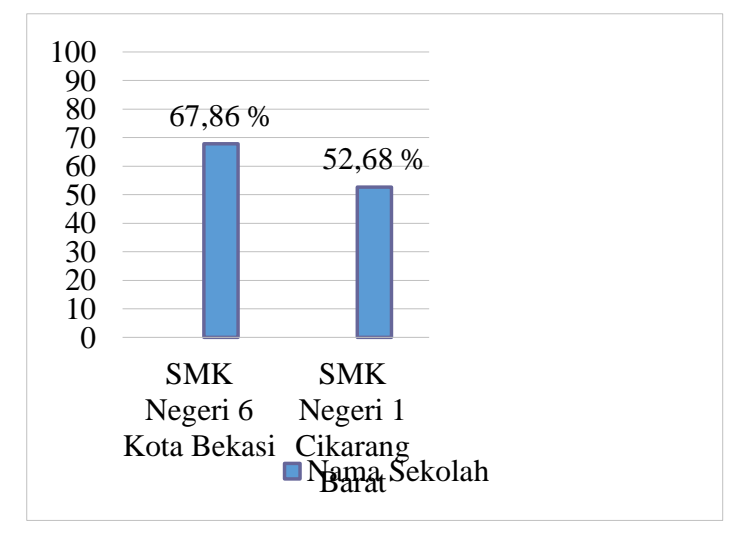


Gambar 6. Rekapitulasi Ketersediaan sarana Ruang Praktik

Berdasarkan hasil ketersediaan sarana ruang praktik dikedua sekolah tersebut, dapat dinyatakan bahwa saran ruang praktik yang ada dengan kondisi baik atau persentase kelayakan di kedua sekolah tersebut yaitu 100\% dengan kategori sangat layak. Berikut ini ini adalah diagram rekapitulasi rata-rata kelayakan sarana ruang praktik Kompetensi keahlian DPIB yang ditunjukkan pada gambar 7.

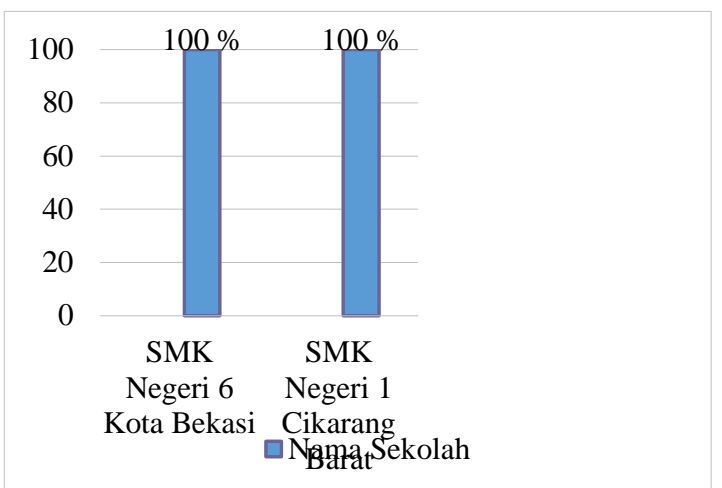

Gambar 7. Rekapitulasi Kelayakan Sarana Ruang Praktik

Walaupun secara keseluruhan sudah dikategorikan layak, semua pihak yang menggunakan sarana ruang praktik diharapkan dapat menjaga dengan baik dan dapat melakukan perawatan komponen sarana dan prasarana secara berkala, serta pihak sekolah dapat menambah sarana yang kurang ataupun yang belum tersedia, sehingga dengan ketersediaan dan kelayakan sarana ruang praktik inilah mampu meningkatkan hasil belajar siswa, karena menurut Mahmud, dkk (2019) mengemukakan bahwa sarana bengkel atau sarana praktik yang semakin baik serta ditunjang dengan kinerja guru praktikum yang baik pula, maka keterampilan praktik siswa juga akan semakin meningkat.

\section{Kelayakan Prasarana Ruang Praktik}

Luas Minimum ruang praktik Kompetensi Keahlian DPIB dalam Permendikbud No. 34 tahun 2018 adalah 150 $\mathrm{m}^{2}$. Luas ruang praktik yang disebut Lab.Komputer DPIB di SMK Negeri 6 Kota Bekasi yaitu $96 \mathrm{~m}^{2}$ yang digunakan untuk menampung 33 sampai 36 siswa. Berdasarkan hasil observasi langsung di lapangan, pada kompetensi keahlian DPIB SMK Negeri 6 Kota Bekasi terdapat satu ruang praktik desain masinal dan komputer dengan rasio 88,89\% atau 2,66 $\mathrm{m}^{2}$ /peserta didik. Rasio yang seharusnya menurut Permendikbud No. 34 Tahun 2018 yaitu sebesar $3 \mathrm{~m}^{2}$. Kompetensi keahlian DPIB di SMK Negeri 6 Kota Bekasi tidak memiliki sub ruang instruktur dan ruang penyimpanan walaupun terdapat 6 orang instruktur dan satu orang toolman dan tidak memiliki ruang perencanaan dan pembuatan model/maket bangunan, sehingga total rata-rata kelayakan prasarana ruang praktik DPIB tersebut sebesar 33,33\% dengan kategori kurang layak.

Ruang praktik DPIB SMK Negeri 1 Cikarang Barat memiliki 2 ruangan yaitu lab.komputer 1 dan lab.komputer 2. Luas ruang lab.komputer 1 yaitu $81 \mathrm{~m}^{2}$ dan luas ruang lab.komputer 2 yaitu $56 \mathrm{~m}^{2}$. Ruangan tersebut digunakan untuk melakukan pembelajaran kejuruan yang menggunakan komputer dan menampung 19 sampai 36 siswa DPIB. Berdasarkan hasil observasi langsung, ruang praktik desain masinal dan komputer 1 (lab.komputer 1) memiliki persentase rasio 75\% atau 2,25 $\mathrm{m}^{2}$ / peserta didik dan ruang praktik desain masinal dan komputer 2 (lab.komputer 2) $51,85 \%$ atau $1,55 \mathrm{~m}^{2} /$ peserta didik. Rasio yang seharusnya menurut Permendikbud No. 34 Tahun 2018 yaitu sebesar $3 \mathrm{~m}^{2}$. Untuk sub ruang instruktur dan ruang penyimpanan memiliki persentase rasio 177,27\% atau 5,32 $\mathrm{m}^{2}$ /instruktur, dengan standar minimum yang berlaku $3 \mathrm{~m}^{2} /$ instruktur. Prasarana ruang Praktik DPIB tidak memiliki ruang perencanan dan pembuatan model/maket bangunan. Secara rata-rata keseluruhan sarana ruang praktik DPIB 56,25\% dengan kategori layak.

Berikut ini ini adalah diagram rekapitulasi rata-rata kelayakan prasarana sarana ruang praktik Kompetensi Keahlian DPIB yang dinjukkan pada gambar 8. 


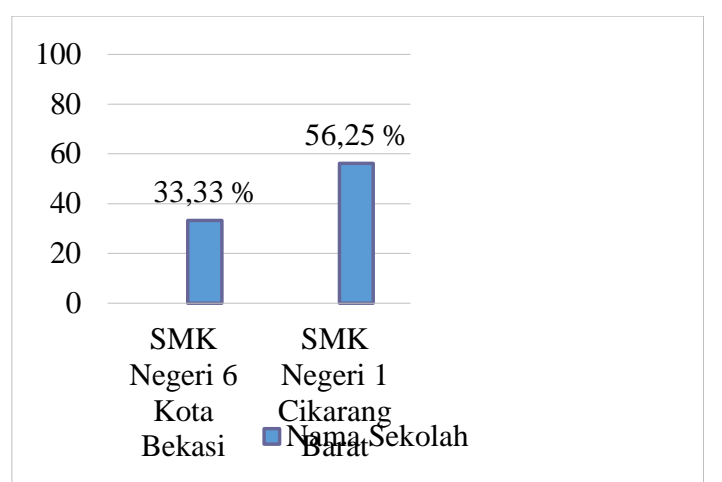

Gambar 8. Rekapitulasi Kelayakan Prasarana Ruang Praktik

Berdasarkan data di atas masih tergolong rendahnya kelayakan dari prasarana ruang praktik di kedua sekolah. Oleh karena itu, pihak sekolah dapat menambah prasarana ruang praktik belum tersedia, serta semua pihak dapat menggunakan dan merawat prasarana ruang praktik dengan baik. Kurangnya prasarana ruang praktik akan berpengaruh terhadap kegiatan pembelajaran dan tujuan pembelajaran yang ingin dicapai, hal tersebut sejalan dengan penelitian Rahardiani, dkk (2017) menjelaskan bahwa dengan memenuhi tingkat kelayakan prasarana praktik dengan standar sarana dan prasarana yang berlaku maka pelaksanaan kegiatan praktik dapat berjalan dengan lancar, dan siswa dapat praktik sesuai dengan tujuan pembelajaran yang akan dicapai.

\section{KESIMPULAN}

Berdasarkan analisis hasil penelitian dan pembahasan pada bab sebelumnya, maka kesimpulan dalam penelitian ini adalah tingkat kelayakan sarana dan prasarana SMK Kompetensi Keahlian DPIB di Kota Bekasi dalam hal ini adalah SMK Negeri 6 Kota Bekasi terdapat sarana dan prasarana yang dikategorikan kurang layak, layak hingga sangat layak menurut Permendikbud No. 34 Tahun 2018 yang meliputi: (1) Sarana ruang kelas telah tersedia sebesar 75,89\% dengan kategori layak, (2) Kelayakan sarana ruang kelas sebesar 97,80\% dengan kategori sangat layak, (3) Kelayakan prasarana ruang kelas sebesar $81,25 \%$ dengan kategori sangat layak, (4) Sarana ruang praktik telah tersedia sebesar 67,86\% dengan kategori layak, (5) Kelayakan sarana ruang praktik sebesar 100\% dengan kategori sangat layak, dan (6) Kelayakan prasarana ruang praktik sebesar 33,33\% dengan kategori kurang layak.

Tingkat kelayakan sarana dan prasarana SMK Kompetensi Keahlian DPIB di Kabupaten Bekasi dalam hal ini adalah pada kompetensi keahlian DPIB di SMK Negeri 1 Cikarang Barat terdapat sarana dan prasarana yang dikategorikan kurang layak, layak hingga sangat layak menurut Permendikbud No. 34 Tahun 2018 yang meliputi: (1) Sarana ruang kelas telah tersedia sebesar 57,65\% dengan kategori layak, (2) Kelayakan sarana ruang kelas sebesar 96,30\% dengan kategori sangat layak, (3) Kelayakan standar prasarana ruang kelas sebesar 50\% dengan kategori kurang layak, (4) Sarana ruang praktik telah tersedia sebesar 52,68\% dengan kategori layak, (5) Kelayakan sarana ruang praktik sebesar 100\% dengan kategori sangat layak, dan (6) Kelayakan prasarana ruang praktik sebesar $56,25 \%$ dengan kategori layak.

Berdasarkan hasil penelitian, pebahasan dan kesimpulan, maka peneliti memberikan saran untuk pihak sekolah yakni dengan diketahuinya jumlah ketersediaan dan kondisi kelayakan sarana dan prasarana yang sudah layak maka pihak sekolah dapat memelihara sarana dan prasarana tersebut dengan baik dan yang belum layak atau belum tersedia maka hendaknya pihak sekolah dapat memenuhi ketersediaan sarana dan prasaran tersebut. Bagi peneliti yang ingin melakukan penelitian sejenis, penelitian ini dapat digunakan sebagai rancangan atau acuan untuk mengembangkan instrumen penelitian dan populasi yang lebih luas.

\section{REFERENCES}

Agusti, R. D., Handoyo, S. S., \& Musalamah, S. (2014). Analisis Pelaksanaan Prosedur Operasional Standar Sarana dan Prasarana Belajar Laboratorium Berdasarkan Manajemen Mutu ISO 9001:2008 \& IWA 2:2007 di Jurusan Teknik Sipil Universitas Negeri Jakarta. Jurnal Pendidikan Teknik Sipil, III(1), 50-61.

Andrianto, J., Helmi, N., Purwantono, P., \& Indrawan, E. (2020). Pengaruh Kondisi Ruang Kelas Terhadap Konsentrasi Belajar Siswa Mata Pelajaran PDTM di SMK Negeri 5 Padang. Jumal Vokasi Mekanika, 2(4), $147-153$.

Atmaja, E., \& Maulana, A. (2020). Hubungan Pemanfaatan Laboratorium Gambar Dengan Hasil Belajar Siswa (Studi pada Mata pelajaran Menggambar dengan Perangkat Lunak pada Kompetensi Keahlian DPIB SMK Negeri 6 Kota Bekasi). Jurnal Pendidikan Teknik Sipil, 9(3), 138-145. 
Havidotinnisa, S. (2016). Kontribusi Pemanfaatan Sarana dan Prasarana Terbadap Kinerja Pebelajaran Sekolah Menengah Kejuran Jamblang Kabupaten Cirebon. Skripsi. Universitas Pendidikan Indonesia.

Ilomo, O., \& Mlavi, B. (2016). The Availability of Teaching and Learning Facilities and Their Effects on Academic Performance in Ward Secondary Schools in Muheza - Tanzania. International Journal of Education and Research, 4(6), 571-582.

Jannah, S. N., \& Sontani, U. T. (2018). Sarana dan Prasarana Pembelajaran Sebagai Faktor Determinan Terhadap Motivasi Belajar Siswa. Jurnal Pendidikan Manajemen Perkantoran, 3(1), 63-70.

Japung, A. (2020). Banyak Sekolah Meja Kursinya Rusak, Begini Kata Kabid SMP Disdik Kot Bekasi. https://toptime.co.id/banyak-sekolah-meja-kursinya-rusak-begini-kata-kabid-smp-disdik-kota-bekasi/. Diakses 4 Februari 2021.

Khairat, F., Handoyo, S. S., \& Arthur, R. (2018). Hubungan Antara Persepsi Siswa Tentang Kompetensi Profesional Guru dengan hasil Belajar Siswa. Jurnal Pendidikan Teknik. Sipil, 7(1), 1-12.

Konstruksi, D. J. B. (2019). Sertifikasi Tenaga Kerja Konstruksi (Edisi 2). Jakarta: Media Informasi dan Komunikasi Direktorat Jendral Bina Konstruksi Kementerian Pekerjaan Umum dan Perumahan Rakyat.

Mahmud, A., Djaelani, A. R., \& Apriyanto, N. (2019). Pengaruh Sarana dan Prasarana Bengkel dan Kinerja Guru Praktikum Terhadap Keterampilan Praktik Sistem Kelistrikan Bodi. Journal of Vocational Education and Automotive Technology, 1(2), 1-7.

Miski, R. (2015). Pengaruh Sarana dan Prasarana Terhadap Hasil Belajar Siswa. Jurnal Tadbir Muwabid, 4(2), 17-21.

Rahardiani, A. P., Sukatiman, S., \& Haris, A. (2017). Analisis Kelayakan Sarana dan Prasarana Praktik di Bengkel Teknik Konstruksi Batu dan Beton SMK Negeri 5 Surakarta. Indonesian Journal of Civil Engineering Education, 3(1), 4-16.

Sabella, A., Syafei, H., Habibah, U., \& Saraswati, R. R. (2020). Analysis of Chemical Laboratory Management at SMAN 55 Jakarta. Risenologi, 5(1), 70-79.

Siswanto, E., \& Hidayati, D. (2020). Management Indicators of Good Infrastructur Facilities To Improve School QUality. International Journal on Education, Management and Innovation (IJEMI), 1(1).

Sudiyono, S., \& Alip, M. (2016). Evaluasi Sarana dan Prasarana Bengkel Praktik SMK Teknik Pemesinan di Kota Semarang Berdasarkan Kebutuhan Kurikulum. Jurnal Pendidikan Vokasi, 6(1), 79-93.

Sugiyono, S. (2018). Metode Penelitian Kuantitatif, Kualitatif, dan R\&D (cetakan 27). Bandung: Alfabeta.

Suliyarti, R. (2019). Manajemen Pemeliharaan Sarana dan Prasarana Pendidikan Untuk Meningkatkan Kualitas Pendidikan. Skripsi. Universitas Negeri Jakarta.

Syafiq, A., \& Sofyan, H. (2018). Kelayakan Sarana dan Prasarana Praktik Ditinjau dari Standar Sarana dan Prasarana Berdasarkan Peraturan Pemerintah No. 40 Tahun 2008. Jurnal Pendidikan Teknik Otomotif, 24(2), 130-140.

Tambunan, P., Ardhiansyah, M. F., \& Kurniawan, M. G. (2020). Pengaruh Suasana Lingkungan Belajar Terhadap Konsentrasi Belajar Siswa Dalam Mata Pelajaran Produktif. Jurnal Pendidikan Teknik Sipil, 9(3), 165-171. 